\title{
GIFTS AND ACQUISITIONS
}

\section{NEW BOOKS}

The Library's collection of both new and old rare books was augmented in recent months. Dr. Anna S. Starr's gift of a quantity of medical-mystical-astrological works is an extremely valuable addition to the Library, since these books represent a garnering of important and rare works devoted primarily to a fascinating subject. The rarity of the fifty volumes presented may be gauged by checking those volumes that are included in the standard bibliographies. For example, Otto Tachenius His Clavis ... (London, I 677), Wing T97, one copy in America; William Forbes's Considerationes Modestae et Pacificae Controversiarum (London, I658), Wing FI454, only one copy in this country; William Struther's Christian Observations and Resolutions (Edinburgh, I 629), STC 23367, four copies; Thomas Vaughan's A Breif [sic] Natural History ... (London, I669), Wing Vr45, five copies listed. Many others are not listed in bibliographies, but they are almost certainly as rare as the ones mentioned.

Another recent accession helps to fill out the Library's holdings of first editions of American authors. This group includes eighteen first editions by Ambrose Bierce, Robert Montgomery Bird, Willa Cather, Henry W. Herbert, Washington Irving, Robinson Jeffers, Christopher Morley, James Whitcomb Riley, George Santayana, William Gilmore Simms, George Sterling, William Allen White, and Albert Bigelow Paine. Nearly all of these authors are represented by other first editions in the Library. The new acquisitions, valuable in their own right, supplement the value of these previously held editions.

Two other recent accessions have assumed a place in our collection of books primarily of New Jersey interest, but they certainly have a wider interest as well. One is a delightful jeu d'esprit entitled Les Enfans Perdus: or the Diabolical Plot (Newark, Muckleby $\mathcal{E}^{2}$ Co., I 863). Everything about the book, from the publisher's name on, is a joke. The author, Andrew D. Fowler (alias Anno Domini for this book), was an occasional writer for the Newark Daily Advertiser, free-lance lecturer, insurance salesman, and dis- 
ciple of Artemus Ward. In the book he gives free rein to his sometimes doubtful wit at the expense of prominent fellow townsmen who are only slightly concealed by anagrammed names. The slight plot centers on a disastrous fishing expedition that assumes epic proportions (in a local way) and remains amusing even after nearly one hundred years. The other accession is not at all humorous, being "An Affecting Narrative of the Tragical Death of Miss Fanny Salisbury, A Native of New Jersey, Who, having been enticed from her widowed parent and basely seduced by a young man of the city of New-York, after enduring incredible hardships in that city, terminated her own existence by hanging herself in a forest near Newark, on the 23 d of January last," entitled The Victim of Seduction (Boston, Printed for Artumus Belcher, 1820). The pamphlet contains only twenty-four pages, printed on cheap paper and is now exceedingly rare. Sabin, 99424, lists only one copy, at Harvard. I was unable to determine whether it is the history of an actual event, as it purports to be, or fiction. If it is fictional, as I suspect, the author has managed to give the story a convincing verisimilitude unusual for the period in which it was written.

\section{MANUSCRIPTS}

The Symington Collection of manuscripts and letters of English authors of the late nineteenth and early twentieth century, one of the most valuable research collections in this library, has recently been supplemented by an acquisition of about I 30 manuscripts and letters. This "Symington Collection Supplement" centers around Sir Edmund Gosse, including some twenty letters and manuscripts in his hand, and perhaps twice as many letters received by him from such men as W. D. Howells, Henry Harland, A. E. Housman, and others. There are many other fine letters to various recipients from Swinburne, the Rossettis, Robert Bridges, Augustine Birrell, and others. Certain of the letters form very interesting groups: the thirteen letters from Henry Harland to Gosse, for example, or the four letters from W. D. Howells to Gosse, which will be edited in a later issue of the Journal.

Of all New Jersey's native sons, Woodrow Wilson is no doubt the most prominent. For that reason Rutgers University is deeply grateful to Dr. Karl A. Meyer of Chicago, Illinois, for giving the 
Library his collection of twenty-eight letters of Wilson, his wife, and others closely associated with him. The letters span Wilson's career, but most of them were written in his earlier years, as president of Princeton and governor of New Jersey. The earliest letter in the collection was written September I0, I896, to Richard Watson Gilder; the last in Wilson's hand was written December 3 I, I923, just a month before his death. The letters discuss a variety of subjects and are directed to a variety of recipients, but each one illustrates Wilson's cordiality and intelligence.

The Rutgers University Library was fortunate to receive through Justice Clarence E. Case, class of 1900 and executor of the estate of John A. Roebling, a large part of the papers of Washington A. Roebling, another of New Jersey's most prominent sons. While Washington Roebling is most famous for his part in the building of the Brooklyn Bridge, he was also a distinguished participant in the Civil War. The Roebling papers now in the Library are concerned chiefly with his service in the Civil War. He enlisted as a private in the New York militia in June, I86I, received a commission as second lieutenant in January, 1862 , and resigned as a lieutenant colonel in January, I 865. He was on General Hooker's staff during the battle of Chancellorsville, and his comments on Hooker's behavior during the battle are valuable indeed. He was one of the closest observers of the battle between the Monitor and the Merrimac and criticized the tactics of the commander of the Monitor: "We could see no reason why the Monitor should not have taken a position stern of the Merrimac and raked her fore and aft. But a Farragut was not on board."* He was also at Gettysburg and fifteen other engagements, from the first Battle of Bull Run to the Wilderness Campaign. Furthermore, he was the first man to make balloon ascensions for reconnaissance and successfully constructed suspension bridges for the army, while protesting correctly that pontoon bridges were far more practical. Many of the best war letters are addressed to Miss Emily Warren, who later became his wife. These letters are an interesting blend of courtship and war correspondence. Although there have been several biographies of the Roeblings, the latest, D. B. Steinman's The Builders of the Bridge, published in I 945, most of the papers now in the Rutgers University Library

\footnotetext{
* Letter to Raymond Arnot, August 31, 1922.
} 
have not been published in any form and remain an untapped source of information on the Roebling family and the Civil War.

Many other recent manuscript accessions deserve description, but because of limitations of space they may only be mentioned. I. Robert Kriendler, class of 1936 and currently a trustee of Rutgers, donated a galley proof of Hemingway's The Old Man and the Sea and a copy of Love and Friendship, a melodrama by A. B. Lindsley (New York, I 809), with an interleaved manuscript adaptation done in 1839 by Edward Davenport, well-known American actor and father of Fanny Davenport. H. Richard Segoine, class of I 908, presented copies of John Forman's field-books (the originals having been destroyed) and maps of East Jersey, covering the period from I 782 to 1807 . From the William Clark estate the Library received the minutes of the board of the New York, Susquehanna, and Western Railroad Company for the period after its bankruptcy, 1937I 940. Paul L. Opdyke gave the records of the Mansfield Vigilant Society, I 876-I 957, to the Library, adding to our collection of papers of similar societies. Four accessions help fill in our collection of source material of early New Jersey history: a copy of the Nottingham Township minute book for the period I692-I7IO; the letter book of Samuel Allinson, covering the years from I764 to I790; a group of "Certificates of Abandonment for Negro Children Born of Slave Parents," I 805-1807, a gift of Piscataway Township; and Elmer T. Hutchinson's biographical and bibliographical notes on early New Jersey printers and publishers, arranged with additions by George C. Rockefeller. From the estate of Elizabeth R. Baldwin came a very large accession of manuscript material of the Bayard, Baldwin, Rutgers, and associated families. The papers are rich in detail about early business in New York and northern New Jersey, some items dating back to the middle seventeenth century.

Other manuscripts were presented to the Library by Lester W. Perrin, Far Hills, New Jersey; Norman C. Wittwer, Oldwick, New Jersey; the West Virginia University Library; Peter Bigler of Milltown, New Jersey; Dr. Broadus Mitchell, Rutgers Department of Economics; H. Kels Swan, class of I952, Bound Brook, New Jersey; and Bela Benczik, Mrs. Mildred V. Boylan, and Mrs. Asher Atkinson, all of New Brunswick, New Jersey. 